\title{
Shakespearean Charactonyms in Translations into Russian
}

\author{
Alexander Kalashnikov \\ National Research University Higher School of Economics
}

\begin{abstract}
Correspondence concerning this article should be addressed to Alexander Kalashnikov, English Language Department for Humanities, National Research University Higher School of Economics, 20 Myasnitskaya

Ul., Moscow, Russian Federation, 101000. E-mail: avkalashnikov@hse.ru
\end{abstract}

\begin{abstract}
Despite a long tradition of translating Shakespeare's works into Russian, names as a stylistic device have been underestimated by scholars. The study deals with the space or environment of characteristic names (charactonyms) and its rendering into Russian in the works Henry IV, Part II and The Merry Wives of Windsor. The material for the research is a dozen translations into Russian done in the nineteenth and the twentieth centuries including annotated editions which may show additional interpretations of the names. Comparing the puns based on names and their equivalents as a method shows how to identify overlapping approaches to translating stylistic devices involving charactonyms. The analysis of the translations reveals a variety of ways to render names, in particular within text, which is rare, and the application of commentaries in annotated editions. This research demonstrates that some equivalents of names have been repeated in several translations and hence the translators relied on the best practice instead of suggesting their own solutions. The research also shows the strategies and patterns employed by Russian translators and writers, which may be a good resource for literary translators.
\end{abstract}

Keywords: Shakespearean onomastics, charactonyms, literary translation, translation into Russian

Shakespeare'sinterest in names as more thantags for distinguishing one character from another manifested itself early in his career. He carried over names from his source books, or when altering such names or adding characters with new ones, chose his invented names on grounds of propriety for poetic utterance, mood, or of natural origin. There are, however, a number of names throughout the canon which have figurative overtones. One such group clusters around personality traits or characters' occupation. Early English drama abounds in examples of charactonyms or label names. The works of the first half of the sixteenth century such as Bale's King John and Udall's Ralph Roister Doister well illustrate this technique with names: Usurped Power, Treason, Sedition, Commonalty, Nobility (Bale, 1838, p. 1), Mathew Merygreeke, Gawyn Goodluck, Margerie Mumblecrust (Udall, 1869, p. 1). Yet Shakespeare's immediate predecessors Lily, Greene, Peele, Marlow, and Kyd - showed little interest in such nomenclature. The Bard's fascination for the possibilities of charactonyms was partially a return to an older tradition. Shakespeare with his own transparent name was keen on applying puns not only to fictional names but to those of real people, e.g., Sir
Henry Percy Hotspur.

The paper will identify the key charactonyms from the historical playHenry IV, Part 2 (hereafter Henry IV) and the comedy The Merry Wives of Windsor as well as puns involving names, and expose those which are relevant to rendering into Russian and the equivalents suggested in several translations. The comparison of the name stems and the equivalents will show the difference in the register of the names. Some names will be considered as being controversial in terms of rendering. The method for comparing puns will show how to identify overlapping solutions to translating puns. The names under examination are represented in Appendices A and B.

The paper argues that translators borrow the equivalents for charactonyms from early translations. Hence, the author aims to show the most relevant names in Shakespeare to be rendered, the strategies provided by translators in several versions, and demonstrate the equivalents of charactonyms borrowed by translators. The topicality of the research is that the analysis of the names will show which episodes require additional attention when translating. As the research is devoted to the names in the works belonging to the 
canon of British and world literature requiring new interpretations and translations, guidelines will be provided for practicing translators to look back at what has been done and justify their variants on the basis of the suggested ones. Moreover, the works analyzed require new translations into Russian as the latest ones were carried out more than half a century ago (Shakespeare, 1959a, b). Besides, the study introduces the Russian translation tradition of Shakespeare's works with 12 translations. The material for the names to be examined in the paper may be of interest as the number of translations (12 in total, 6 for each play) taken for comparison is unprecedented in both translation theory and onomastic studies. The attempt to examine the onymic space in the translation of the works by Shakespeare into Russian is being done for the first time.

The studies of Shakespearean onomastics in translations are not extensive. Earlier commentaries and papers on this topic are the annotated edition of The Twelfth Night (Shakespeare, 1901) containing explanations for German readers regarding names, as even the versions rendered in German did not seem convincing to the editors; and the paper by scholar Maria Barros Ochoa (1992) with classified most representative examples of rendering charactonyms into Spanish on a rather wide material of Shakespeare's works in translation. The selected names rendered in translation were arranged in three groups: conservation of the English form, phonological adaptation and translation (Ochoa, 1992).

In a more recent paper, Gomes da Torre (2004), one of the translators of Measure for Measure, suggests his solutions to rendering wordplay with names and compares his versions to some previous solutions in translations. That paper traces the reasons for the choice of particular names and contexts in Shakespeare's play and concludes on the inconsistencies in the choice of names in the play per se and in translations (Gomes da Torre, 2004, p. 208). A special attention was given to the contexts involving names Pompey, Overdone, Abhorson, and Shoetie. The comparison of the Portuguese equivalents such as Recozida, Desgastada and Desgaste for Overdone (Gomes da Torre, 2004, p. 212) or Abominancio and Unhas-de-Fome for Abhorson (Gomes da Torre, 2004, p. 215) emphasizes the postulate that every translator should decide which meanings and overtones in translation are obligatory and which ones may be missed out.

\section{Materials and Methods}

The research aims to show the stems used in the Russian translations to transferthe stylistic relevance of charactonyms and to expose the names requiring additional rendering. To achieve the objective, the variety of the names has been reduced to the most representative charactonyms in Shakespeare's plays and their translations. The suggestion is expressed that some Russian translations made the text more vulgar. The names were organized into lists with the equivalents given in the translations and compared (see Appendices A and B). Special attention in this regard has been given to puns, which are the core of Act III, scene II of Henry IV.

The characters surrounding Falstaff in translation have not been studied though Shakespeare's use of charactonyms in Henry IV stands as pivotal. On the one hand, it reflects his earlier interest in meaningful names in their simplest form - mirroring a specific personality or occupation trait of a character without any significant role in the play. On the other hand, it shows him combining the possibilities of humorous characterization. The Merry Wives of Windsor presents greater sophistication in these respects than Henry IV does. The names studied and classified are restricted to the characters associated with Falstaff.

As Shakespeare played the name game, he did not limit himself to any one genre. The comedies, tragedies, and histories all contain characters whose appellations have been determined by their traits or occupations. Many charactonyms are part of the dramatis personae list, which shows their significance for the plot. In Henry IV, they are: Pistol, Shallow, Silence, Fang, Snare, Tearsheet, Quickly. The recruits whom Shallow gathered for Falstaff were called Mouldy, Shadow, Wart, Feeble, and Bullcalf (see Appendices B and C). As Falstaff addresses them in Act III, scene II, he manages to make some remarks reflecting on their names. A similar enumeration of names has been mentioned in the same act earlier (Shakespeare, n.d., p. 512) but then the names derived from other words were not explained. In this case, they may be referred to as intersemantisizing names (see Kalashnikov, 2013), i.e., they acquire some stylistic characteristics not because of the interpretation of the morphemes but because of their location within the same context: Doit (a coin), Double (double-faced), Pickbone (to have a bone to pick with somebody) etc. Such names being inexpressive are less relevant to translation. In total, the study has revealed 9 charactonyms in The Merry Wives of Windsor (see Appendix A) and 28 in Henry IV (see Appendix B). However, some of the names overlap: Quickly, Pistol, Silence, Shallow. Despite the feature of characterization, the names are neutral in register,with a share containing a negative connotation.

The translations of The Merry Wives of Windsor selected for this study were performed by N. Ketcher (Shakespeare, 1862), P. Veinberg (Shakespeare, 1902), L. Kanshin (Shakespeare, 1894b), V. Moritz and M. Kuzmin (Shakespeare, 1937a), T. Schepkina-Kupernik 
(Shakespeare, 1950), M. Morozov and S. Marshak (Shakespeare, 1959a). The translation of the inner form in the names in Henry IV deserves attention as this historical play was one of the first translations of any Shakespeare's work into Russian. The rendering This 'tis to have Linen and Buckbaskets with the setting in Saint Petersburg was done by the Russian empress Catherine the Great (Catherine II, 1893). She suggested the names Фордов for Ford and Папина ( $\approx$ father's) for Anne Page. Later, the translations of Henry IV were done in the nineteenth century by N. Ketcher (Shakespeare, 1869), L. Kanshin (Shakespeare, 1894a), then by A. Vengerova and N. Minskiy (Shakespeare, 1902). In the Soviet period, the work was translated by M. Kuzmin (Shakespeare, 1937a), B. Pasternak (Shakespeare, 1948), E. Birukova (Shakespeare, 1959b). Birukova's translation is the latest so far. Of note, translators Ketcher, Kanshin, Kuzmin, Morozov translated both works.

\section{Results and Discussion}

Disclosing characteristic traits in names was based on the contextual analysis which identifies a certain association between the name and some trait or occupation, e.g., Pistol and Smooth are a soldier and silkman respectively. Shallow characterizes justice. With few exceptions, Shakespeare restricted such names to the lower class characters. For the complete list of characteristics, see Appendices A and B.

Most names are transcribed or transliterated when being characteristic in Russian literature. Some do not require any transformation which may be understood as the name contains an internationally recognizable stem. Among the formal approaches to rendering names, there is transliteration, notes / commentaries, and footnotes. Some names specified as characteristic may be rendered without many changes, i.e., Pistol, Nym. The former represents an international stem with the same meaning - a pistol. The latter is characteristic but historically as the word nym used to be derived from Middle English nimen 'to take' and is applied in the play to represent a rogue or filcher. The meaning and characteristics of the names is vague even for the current native English readers so it may deem irrelevant to explicate the meaning unless an untranslated name hampers understanding, e.g., the translation done by Moritz and Kuzmin (Shakespeare 1937a, 1937b) with minimal explanations. The puns or amusing misuse of words resembling in different languages, e.g., Hannibal - Cannibal in Henry IV (Act II, Scene IV) (Shakespeare, n.d., p. 508) do not require any additional rendering either. The names in Henry $I V$ rendered without showing the inner form are (see also Appendices A and B):

Ketcher: Quickly, Silence, Surecard, Snarre, Fang, Tearsheet,Doit, Barnes, Pickbone, Squele, Stockfish, Double, Nightwork, Smooth, Shallow;

Kanshin: Quickly, Silence, Doit, Barnes, Tearsheet, Pickbone, Squele, Stockfish, Double, Nightwork, Smooth, Shallow;

Vengerova: Quickly, Doit, Barnes, Tearsheet, Pickbone, Squele, Stockfish, Double Nightwork, Smooth;

Pasternak: Quickly, Squeel, Double, Tearsheet, Nightwork, Shallow;

Birukova: Quickly, Snare, Fang, Tearsheet, Barnes, Smooth, Shallow.

The least popular for translation were the following names: Quickly, Tearsheet, Silence, Doit, Pickbone, Squele, Stockfish, Double, Nightwork, Smooth. As Quickly and Silence are major characters, their characteristics are shown through the entire description without any focus on the forms of the names. The largest number of the names untranslated at the level of the characteristic concept has occurred in Ketcher's text - the first translation of the play. In the latest translation of The Merry Wives of Windsor, Morozov and Marshak applied only transliteration without commentaries. The names of minor characters about who we do not know anything and possess the so called intersemantisizing meaningfulness were left untouched. The traces that the translations did not show as being explicit amoral characteristics are seen in not rendering the names of characters with suggestive names Doll Tearsheet and Jane Nightwork. The most frequent variants of transliteration or rendering are given in Table 1.

Table 1

Frequency of transliterated equivalents

a)The Merry Wives of Windsor

\begin{tabular}{lcccc}
\hline $\begin{array}{l}\text { English } \\
\text { name }\end{array}$ & Pistol & Nym & Quickly & Shallow \\
\hline $\begin{array}{l}\text { Russian } \\
\text { equivalent } \\
\text { (frequency) }\end{array}$ & $\begin{array}{c}\text { Пистоль } \\
(4)\end{array}$ & $\begin{array}{c}\text { Ним } \\
(4)\end{array}$ & $\begin{array}{c}\text { Куикли } \\
(4)\end{array}$ & $\begin{array}{c}\text { Шеллоу } \\
(3)\end{array}$ \\
\hline $\begin{array}{l}\text { English } \\
\text { name }\end{array}$ & Slender & Simple & Brook & \\
\hline $\begin{array}{l}\text { Russian } \\
\text { equivalent }\end{array}$ & $\begin{array}{c}\text { Слендер } \\
(4)\end{array}$ & $\begin{array}{c}\text { Симпль } \\
(4)\end{array}$ & $\begin{array}{c}\text { Брук } \\
(2)\end{array}$ & \\
\hline $\begin{array}{l}\text { b)Henry IV } \\
\text { English }\end{array}$ & $\begin{array}{c}\text { Ріstol } \\
\text { name }\end{array}$ & Quickly & $\begin{array}{c}\text { Doll } \\
\text { Теarsheet }\end{array}$ & Silence \\
\hline $\begin{array}{l}\text { Russian } \\
\text { equivalent } \\
\text { (frequency) }\end{array}$ & $\begin{array}{c}\text { Пистоль } \\
(6)\end{array}$ & $\begin{array}{l}\text { Квикли (3) } \\
\text { Куикли (3) }\end{array}$ & $\begin{array}{c}\text { Tepшит } \\
(4)\end{array}$ & $\begin{array}{c}\text { Сайленс } \\
(5)\end{array}$ \\
\hline $\begin{array}{l}\text { English } \\
\text { name }\end{array}$ & $\begin{array}{l}\text { Surecard } \\
\text { Snare }\end{array}$ & Fang & Doit \\
\hline
\end{tabular}




\begin{tabular}{|c|c|c|c|c|}
\hline $\begin{array}{l}\text { Russian } \\
\text { equivalent }\end{array}$ & $\begin{array}{l}\text { Шуркард } \\
\text { (3) }\end{array}$ & $\begin{array}{l}\text { Силок (2) } \\
\text { Снер (2) }\end{array}$ & $\begin{array}{c}\text { Коготь } \\
(3)\end{array}$ & $\begin{array}{c}\text { Дойт } \\
(4)\end{array}$ \\
\hline $\begin{array}{l}\text { English } \\
\text { name }\end{array}$ & Barnes & Pickbone & Stockfish & Squele \\
\hline $\begin{array}{l}\text { Russian } \\
\text { equivalent }\end{array}$ & $\begin{array}{c}\text { Барнс } \\
(4)\end{array}$ & Пикбон (6) & $\begin{array}{c}\text { Стокфиш } \\
(4) \\
\end{array}$ & Скуил (3) \\
\hline $\begin{array}{l}\text { English } \\
\text { name }\end{array}$ & Double & $\begin{array}{c}\text { Jane } \\
\text { Nightwork }\end{array}$ & Gaunt & Smooth \\
\hline $\begin{array}{l}\text { Russian } \\
\text { equivalent }\end{array}$ & $\begin{array}{c}\text { Дебль } \\
\text { (5) }\end{array}$ & $\begin{array}{c}\text { Найтуорк (2) } \\
\text { Ночная } \\
\text { Пташка (2) }\end{array}$ & $\begin{array}{c}\text { Гонт } \\
(6)\end{array}$ & $\begin{array}{l}\text { Смут } \\
\text { (5) }\end{array}$ \\
\hline $\begin{array}{l}\text { English } \\
\text { name }\end{array}$ & Shallow & Mouldy & Shadow & Wart \\
\hline $\begin{array}{l}\text { Russian } \\
\text { equivalent }\end{array}$ & $\begin{array}{c}\text { Шеллоу } \\
\text { (5) }\end{array}$ & Плесень (3) & $\begin{array}{l}\text { Тень } \\
(5)\end{array}$ & $\begin{array}{c}\text { Бородавка } \\
(4)\end{array}$ \\
\hline $\begin{array}{l}\text { English } \\
\text { name }\end{array}$ & Slender & Simple & Brook & Shallow \\
\hline $\begin{array}{l}\text { Russian } \\
\text { equivalent }\end{array}$ & $\begin{array}{c}\text { Слендер } \\
\text { (4) }\end{array}$ & Симпль (4) & $\begin{array}{c}\text { Брук } \\
\text { (2) }\end{array}$ & $\begin{array}{l}\text { Шеллоу } \\
\text { (5) }\end{array}$ \\
\hline $\begin{array}{l}\text { English } \\
\text { name }\end{array}$ & Feeble & Bullcalf & Hotspur & \\
\hline $\begin{array}{l}\text { Russian } \\
\text { equivalent }\end{array}$ & $\begin{array}{c}\text { Слабняк } \\
\text { (2) } \\
\text { Мозгляк } \\
\text { (2) }\end{array}$ & $\begin{array}{c}\text { Бычок } \\
\text { (4) }\end{array}$ & $\begin{array}{l}\text { Commen- } \\
\text { taries (4) }\end{array}$ & \\
\hline
\end{tabular}

Having been transliterated, most variants targeting charactonyms took advantage of commentaries, with 42 cases of 196 equivalents, i.e., 21\%. Two editions had commentaries (in the Appendices 'commentaries' are shortened tocmnt).Thetranslation donebyB.Pasternak is an annotated edition with the commentaries made by D. Urnov. The stems are translated in the notes and include: Surecard - уверенная карта - (sure card), Shallow - пустой - (empty). The commentaries to The Merry Wives of Windsor are less focused on names. The commentaries were added to the translations by Moritz and Kuzmin, Pasternak, Birukova. They were written by Shakespearean scholars A. Smirnov and D. Urnov and may be considered too detailed even for obvious things. As to the remarks on such explanatory notes, it is worth mentioning that the name Barnes was represented in the form Bare and interpreted in the Moritz and Kuzmin edition as naked (Shakespeare, 1937b, p. 677) which is probably a mistake. The original form was Barnes meaning a place to store grain.

The transliteration of charactonyms did not harm the text though made it less vivid. An aspect which might have affected the onymic space is the form of English names which accidentally coincide with Russian words or resemble them making the transliterated form sound ambiguous, in particular the name Caius. The name Caius from The Merry Wives of Windsor associated with a famous seventeenth century doctor John Caius is pronounced as /'ki:z/. In Russian, the name is transliterated but it sounds very similar to the word kayat'sya or ja kayus', i.e., feel sorry, which can add some irrelevant connotation. The same is with the silkman's name Smooth which resembles the Russian smuta - 'strife'. B. Pasternak, the Nobel Prize winner in literature, suggested in his translation the variant Smoos to make the equivalent less resembling. It renders the idea as it sounds like the internationally known word mousse.

As to the thesis of the paper on overlapping variants, the analysis has shown that the equivalents for charactonyms have been repeated in several translations: Плесень (Vengerova, Birukova), Тень (Vengerova, Kanshin, Ketcher, Kuzmin, Birukova); Бородавка (Vengerova, Ketcher, Kuzmin, Birukova); Слабняк (Vengerova, Kuzmin); Бычок (Vengerova, Kuzmin, Birukova); Силок (Vengerova, Kanshin); Коготь (Vengerova, Kanshin, Pasternak); Ночная Пташка (Birukova, Kuzmin). The variants of Vengerova have been applied mostly by Birukova: Плесень, Тень, Бородавка, Бычок. With the major charactonyms in Shakespeare's works being neutral in terms of register though with a taint of negative connotation, the Russian translations contain colloquial variants: Мозгляк (snip) (Birukova, Kanshin), Пискун (squeaker), Блюдолиз (sponger) (Moritz and Kuzmin in commentaries), Гуляка (roister),Тихоня (timid boy) (Vengerova and Minskiy). The variant with the colloquial ending $-y a k$ has been applied twice: Мозгляк, Слабняк. In The Merry Wives of Windsor, other expressive equivalents are Пустозвон (windbag), Слюнтяй (sissy), Простофиля (Simple Simon). The image of characters has not changed except probably Pasternak who rendered the name Shadow аs Облако'cloud'. The translator Schepkina-Kupernik listed double variants on the dramatis personae list and then transliterated names.

A special effort from translators was required by a passage from Henry $I V$ introducing the recruits whom Shallow gathered for Falstaff as they bear names Mouldy, Shadow, Wart, Feeble, and Bullcalf (see Appendix C). As Falstaff addresses each of them, he manages to make some remarks on their names. The comparative analysis of puns (see Appendix B) has shown that puns from the translation by Moritz and Kuzmin were borrowed from the translation of Vengerova and Minskiy, e.g., Плесень (mould), Тень (shadow), Бородавка (wart), Слабняк (softie). Translators Z. Vengerova and N. Minskiy (Shakespeare, 1902) applied an interesting approach with the name Peter Bullcalf having changed the personal regular name Peter to Hector - the name of a Trojan prince and the greatest fighter in the Trojan War - probably to show ironically the courage of the warrior.

In The Merry Wives of Windsor, the primary pun from Act III, Scene V was based on the name Ford: "Mistress Ford! I have had ford enough; I was thrown into the ford; I have my belly full of ford." (Shakespeare, n.d., 
p. 67). The name was transliterated in the translations of M. Kuzmin (Shakespeare, 1937a, p. 364) and M. Morozov (Shakespeare, 1959a, p. 327). The other variants include: Источник (source (Kanshin), Поток (stream (Veinberg), Порт (port (Schepkina-Kupernik).

Besides the mentioned onymic features, Shakespeare was one of the first writers who played with the names of historical figures. In Henry IV, he characterized Sir Henry Percy Hotspur as a fiery warrior and made a pun on his name in Act I, Scene II: “... young Harry Percy's spur was cold? Of Hotspur Coldspur?” (Shakespeare, n.d., p. 496). Birukova, Pasternak, Ketcher, Vengerova rendered it in the text, Kuzmin and Kanshin resorted to footnotes. In The Merry Wives of Windsor, the nobleman John of Gaunt is mentioned. The translators comment on it as a clear association with the word 'gaunt'is evident: "I saw it, and told John a' Gaunt he beat his own name, for you might have thrust him and all his apparel into an eelskin" (Act III, Scene II) (Shakespeare, n.d., p. 515). The other original interpretation of Gaunt as the Belgian place name Ghent is not explained in any edition.

\section{Conclusion}

In this study, a total of $37(9+28)$ names were analyzed in 12 translations and renderings of The Merry Wives of Windsor and Henry IV, Part II. Most names were transliterated. The least popular for translation were the names of either major characters or of those mentioned episodically. However, the analysis of translations has revealedthe ways of rendering names within text, which is rare, or in commentaries in annotated editions prepared by Shakespearean scholars.The commentators suggested literary translation of stems. Descriptive translation was not used and none of the translators omitted text because of names.

The analysis has shown that the equivalents overlapped in several translations. Some names reflecting features at least at a general level of positive or negative naturemay be rendered without many changes, i.e., Pistol, as they represent a stem common in many European languages. Though the major chractonyms in Shakespeare's works being nicknames are neutral in terms of their register, the Russian translations contain colloquial variantsarranged in particular by the ending -yak(a): Мозгляк, Гуляка.

The research has shown the strategies and patterns employed by Russian translators for an extensive period, which is a good resource for literary translators and critics. The limits of a journal paper have provided for a concise analysis of anthroponymy in Shakespeare's works. Hence, the research is reduced to the material of two interconnected and popular works. However, the results presented may be extrapolated to a wider domain of Shakespearean onomastics or English literature in cross cultural research.

\section{References}

Bale, J. (1838). Kynge Johan. London, UK: J. B. Nichols. Catherine II (1849). Vot kakovo imyet' korzinu i byel'e [This 'tis to have linen and buckbaskets]. In Sochineniya imperatritsy Ekateriny II (Vol. 2, pp. 367434). Saint Petersburg, Russia: Izdanie A. Smirdina.

Gomes da Torre, M. (2004). The translation of proper names in measure for measure. In R. M. G. de Carvalho Homem \& T. Hoenselaars (Eds.), Translating Shakespeare for the twenty-first century (pp. 203-216). Amsterdam, Netherlands: Rodopi B. $\mathrm{V}$.

Kalashnikov, A. (2013). Usual and occasional equivalents of charactonyms: Case-study of two translations. Acta Onomastica, 45, 91-100.

Ochoa, M. A. (1992). Traducción de caractónimos enlaobrade William Shakespeare [Transaltion of charactonyms in the works of William Shakespeare]. Estudios humanísticos. Filología, 14, 113-128.

Shakespeare, W. (n.d.). The complete works. New York, NY: P. F. Collier \& Son Company.

Shakespeare, W. (1862). Dramaticheskiya sochineniya Shekspira. Genrikh IV. Chast' 2-ya [The dramatic works of Shakespeare. Henry IV, Part 2]. Moscow, Russia: Izdanie K. Soldatenkova.

Shakespeare, W. (1894a). Genrikh IV. Chast' 2-ya [Henry IV, Part 2]. In Polnoye sobraniye sochineniy $V$. Shekspira $v$ proze $i$ stihah $v 12$ tomah (Vol. 4, pp. 105-216). Saint Petersburg, Russia: Izdanie S. Dobrodeeva.

Shakespeare, W. (1894b). Veselyya uindzorskiya zheny [The merry wives of Windsor]. In Polnoye sobraniye sochineniy $V$. Shekspira $v$ proze i stihah $v 12$ tomah (Vol. 10, pp. 1-93). Saint Petersburg, Russia: Izdanie S. Dobrodeeva.

Shakespeare, W. (1901). Twelfth night: Or, what you will. Philadelphia, PA: Lippiancott Company.

Shakespeare, W. (1902). Polnoe sobranie sochineniy $v 5$ tomakh [The complete works in 5 volumes] (Vol. 2). Saint Petersburg, Russia: Brokgauz-Efron.

Shakespeare, W. (1937a). Veselye vindzorskie kumushki [The merry wives of Windsor]. In Polnoye sobraniye sochineniy $v 8$ tomah (Vol. 1, pp. 481-608). Moscow, USSR: Academia.

Shakespeare, W. (1937b). Genrikh IV. Chast' 2-ya [Henry IV. Part 2]. In Polnoye sobraniye sochineniy $v 8$ tomah (Vol. 3, pp. 367-512). Moscow, USSR: Academia. 
Shakespeare, W. (1948). Genrikh IV [Henry IV]. Moscow, USSR: Detgiz.

Shakespeare, W. (1950). Veselye vindzorskie kumushki [The merry wives of Windsor]. In Izbrannye proizvedeniya (pp. 384-417). Moscow, USSR: Gosudarstvennoe Izdatel'stvo khudozhestvennoy literatury.

Shakespeare, W. (1959a). Vindzorskie nasmeshnitsy: Prevoskhodnaya i priyatnaya komediya o sere Dzhone Fal'stafe i vindzorskikh nasmeshnitsakh
[The merry wives of Windsor: A most pleasant and excellent conceited comedy of Sir John Falstaff and the merry wives of Windsor]. In Polnoe sobranie sochineniy $v 8$ tomakh (Vol. 4, pp. 249-369). Moscow, USSR: Iskusstvo.

Shakespeare, W. (1959b). Genrikh IV, Chast' 2 [Henry IV, Part 2]. In Polnoe sobranie sochineniy $v 8$ tomakh (Vol. 4, pp. 119-247). Moscow, USSR: Iskusstvo.

Udall, N. (1869). Roister Doister. London, UK: Bloomsbury. 


\section{Appendix A}

9 charactonyms and their translations in The Merry Wives of Windsor $(\mathrm{cmnt}=$ commentaries $)$

\begin{tabular}{|c|c|c|c|c|c|c|}
\hline Name & $\begin{array}{l}\text { Characteristics/ } \\
\text { explanation }\end{array}$ & $\begin{array}{c}\text { Kanshin } \\
\text { (Shakespeare, } \\
\text { 1894) }\end{array}$ & $\begin{array}{c}\text { Veinberg } \\
\text { (Shakspeare, } \\
\text { 1902) }\end{array}$ & $\begin{array}{c}\text { Kuzmin } \\
\text { (Shakespeare, } \\
\text { 1937) }\end{array}$ & $\begin{array}{c}\text { Schepkina- } \\
\text { Kupernik } \\
\text { (Shakspeare, } \\
\text { 1950) }\end{array}$ & $\begin{array}{c}\text { Morozov \& } \\
\text { Marshak } \\
\text { (Shakespeare, } \\
\text { 1959) }\end{array}$ \\
\hline Pistol & Soldier & Пистоль & Пистоль & Пистоль & Пистоль & Пистоль \\
\hline Nym & $\begin{array}{l}\text { His name suggests } \\
\text { petty villainy. It } \\
\text { meant 'steal', 'filch' in } \\
\text { Elizabethan English. }\end{array}$ & Ним & Ним & Ним & Ним & Ним \\
\hline Quickly & $\begin{array}{l}\text { Housekeeper. She } \\
\text { rapidly flits around } \\
\text { town in her capacity } \\
\text { as go-between. }\end{array}$ & Куикли & Куикли & Куикли & Куикли (cmnt) & Куикли \\
\hline Shallow & $\begin{array}{l}\text { Laughable country } \\
\text { justice }\end{array}$ & Свищ & Шэлло (cmnt) & Шеллоу & Шеллоу (cmnt) & Шеллоу \\
\hline Slender & $\begin{array}{l}\text { He is slender of body } \\
\text { and slender of mind. }\end{array}$ & Жердь & Слендер & Слендер & Слендер(cmnt) & Слендер \\
\hline Simple & $\begin{array}{l}\text { Slender's servant. He } \\
\text { is no smarter than his } \\
\text { name suggests. }\end{array}$ & Простофиля & Симпль & Симпль & Симпль(cmnt) & Симпль \\
\hline $\begin{array}{l}\text { Brook } \\
\text { Ford }\end{array}$ & $\begin{array}{l}\text { The names Brook and } \\
\text { Ford belong to the } \\
\text { same semantic field - } \\
\text { water features. }\end{array}$ & Источник & Поток & Брук (cmnt) & Порт & Брук \\
\hline
\end{tabular}




\section{Appendix B}

28 charactonyms and puns and their translation in Henry IV

\begin{tabular}{|c|c|c|c|c|c|c|c|}
\hline Name & $\begin{array}{l}\text { Characteristics/ } \\
\text { explanation }\end{array}$ & $\begin{array}{c}\text { Ketcher } \\
\text { (Shake- } \\
\text { speare, 1862) }\end{array}$ & $\begin{array}{c}\text { Kanshin } \\
\text { (Shakespeare, } \\
\text { 1894) }\end{array}$ & $\begin{array}{c}\text { Vengerova } \\
\text { \& Minskiy } \\
\text { (Shakespeare, } \\
\text { 1902) }\end{array}$ & $\begin{array}{c}\text { Moritz\&Kuzmin } \\
\text { (Shakespeare), } \\
\text { 1937) }\end{array}$ & $\begin{array}{c}\text { Pasternak } \\
\text { (Shakespeare, } \\
\text { 1948) }\end{array}$ & $\begin{array}{l}\text { Birukova } \\
\text { (Shake- } \\
\text { speare, } \\
\text { 1959) }\end{array}$ \\
\hline Pistol & Soldier & Пистоль & Пистоль & Пистоль & Пистоль (cmnt) & Пистоль & Пистоль \\
\hline Quickly & See Appendix 1. & Квикли & Куикли & Квикли & Квикли (cmnt) & Куикли & Куикли \\
\hline $\begin{array}{c}\text { Doll } \\
\text { Tearsheet }\end{array}$ & Lover of Falstaff & Тиршить & Тершит & Тиршитъ & Тершит (cmnt) & Тершит & Тершит \\
\hline Silence & Says very little & Сайленсъ & Сайленсъ & Сайленс & Тихоня & $\begin{array}{l}\text { Сайленс } \\
\text { (cmnt) }\end{array}$ & $\begin{array}{l}\text { Сайленс } \\
\text { (cmnt) }\end{array}$ \\
\hline Surecard & $\begin{array}{l}\text { Alludes to a fraudu- } \\
\text { lent person }\end{array}$ & Шюръкардъ & Шуркард & Гуляка & Шуркард (cmnt) & $\begin{array}{l}\text { Шуркард } \\
\text { (cmnt) }\end{array}$ & $\begin{array}{l}\text { Шуркард } \\
\text { (cmnt) }\end{array}$ \\
\hline Snare & $\begin{array}{l}\text { Constable hired to } \\
\text { arrest Falstaff }\end{array}$ & Снарре & Силок & Силокъ & Снер (cmnt) & Клещ & Снер \\
\hline Fang & $\begin{array}{l}\text { Constable hired to } \\
\text { arrest Falstaff }\end{array}$ & Фангъ & Коготь & Коготь & Фенг (cmnt) & Коготь & Фенг \\
\hline Doit & A coin & Дойтъ & Дайт & Дойтъ & Дойт (cmnt) & Доит & Дойт (cmnt) \\
\hline Barnes & $\begin{array}{c}\text { Barn means a farm } \\
\text { building }\end{array}$ & Барнсъ & Барнс & Бэръ & Бер (cmnt) & Барнс & Барнс \\
\hline Pickbone & $\begin{array}{l}\text { The name alludes to } \\
\text { the phrase 'to have } \\
\text { a bone to pick with } \\
\text { somebody' }\end{array}$ & Пикбонъ & Пикбон & Пикбонъ & Пикбон (cmnt) & Пикбон & $\begin{array}{l}\text { Пикбон } \\
\text { (cmnt) }\end{array}$ \\
\hline Squele & To squeal & Скиль & Скуил & Сквиль & Скуиль (cmnt) & Скуил & $\begin{array}{l}\text { Скуил } \\
\text { (cmnt) }\end{array}$ \\
\hline Stockfish & Unsalted fish & Стокфиш & Стокфиш & Штокфишъ & Стокфиш (cmnt) & $\begin{array}{l}\text { Самсон } \\
\text { Треска }\end{array}$ & $\begin{array}{c}\text { Стокфиш } \\
\text { (cmnt) }\end{array}$ \\
\hline Double & Double-faced & Дебль & Дебль & Добль & Дебль (cmnt) & Дебль & Дебль (cmnt) \\
\hline $\begin{array}{c}\text { Jane } \\
\text { Nightwork }\end{array}$ & $\begin{array}{l}\text { Minor character with } \\
\text { a suggestive name }\end{array}$ & Найтворкъ & Найтуорк & Найтворкъ & Ночная Пташка & Найтуорк & $\begin{array}{l}\text { Ночная } \\
\text { Пташка } \\
\text { (cmnt) }\end{array}$ \\
\hline Gaunt & $\begin{array}{l}\text { 1)Embodies } \\
\text { emaciation; } \\
\text { 2) Duke John of Gaunt } \\
=\text { Ghent }\end{array}$ & Гонт & Гонт & Гонт & Гонт (cmnt) & Гонт & Гонт (cmnt) \\
\hline Smooth & Silkman & Смут & Смут & Смут & Смут (cmnt) & Смус & Смут \\
\hline Shallow & See Appendix 1. & Шеллоу & Шэллоу & Пустозвонъ & $\begin{array}{l}\text { Шеллоу } \\
\text { (cmnt) }\end{array}$ & $\begin{array}{l}\text { Шеллоу } \\
\text { (cmnt) }\end{array}$ & Шеллоу \\
\hline Mouldy & Recruit & $\begin{array}{c}\text { Запль } \\
\text { сневьлый }\end{array}$ & Слизь & Плесень & Плесень & Грибок & Плесень \\
\hline Shadow & Extremely thin recruit & ТБнь & Тень & Тень & Тень & Облако & Тень \\
\hline Wart & $\begin{array}{l}\text { Poor, dressed in rags } \\
\text { recruit }\end{array}$ & Бородавка & Прыщ & Бородавка & Бородавка & Лишай & Бородавка \\
\hline Feeble & $\begin{array}{l}\text { Recruit, a woman's } \\
\text { tailor }\end{array}$ & Слабость & Мозгляк & Слабняк & Слабняк & Немочь & Мозгляк \\
\hline Bullcalf & $\begin{array}{l}\text { Recruit, claims to } \\
\text { be ill }\end{array}$ & Бычокъ & Телок & Гектор Бычок & Бычок & Телок & Бычок \\
\hline Hotspur & Military man & $\begin{array}{c}\text { Молодой } \\
\text { Гарри Перси } \\
\text { охладьлъ }\end{array}$ & $\begin{array}{c}\text { И Гарри мой } \\
\text { уже не "Хот", а } \\
\text { "Кольд-спер"? } \\
\text { (cmnt) }\end{array}$ & $\begin{array}{l}\text { Горячій } \\
\text { рыцарь- } \\
\text { сталъо- } \\
\text { стывшим- } \\
\text { трупомъ }\end{array}$ & $\begin{array}{c}\text { И шпора Перси } \\
\text { юного остыла } \\
\text { (cmnt) }\end{array}$ & $\begin{array}{c}\text { Охладела } \\
\text { Готсперо-ва } \\
\text { шпора? (cmnt) }\end{array}$ & $\begin{array}{c}\text { И шпора } \\
\text { Перси юного } \\
\text { остыла } \\
\text { (cmnt) }\end{array}$ \\
\hline
\end{tabular}




\section{Appendix C}

Puns with names Mouldy, Shadow, Wart, Feeble, Bullcalf in Henry IV (III:II)

Falstaff: Is thy name Mouldy?

Mouldy: Yea, an't please you.

Falstaff: 'Tis the more time thou wert used.

Shallow: Ha, ha, ha! most excellent, i' faith! Things that are mouldy lack use: very singular good! in faith, well said, Sir John, very well said. [...]

Shallow: Peace, fellow, peace; stand aside: know you where you are? For the other, Sir John: let me see: Simon Shadow!

Falstaff: Yea, marry, let me have him to sit under: he's like to be a cold soldier. [...]

Falstaff: Is thy name Wart?

Wart: Yea, sir.

Falstaff: Thou art a very ragged wart. [...]

Falstaff: Well said, good woman's tailor! well said, courageous Feeble! thou wilt be as valiant as the wrathful dove or most magnanimous mouse. Prick the woman's tailor: well, Master Shallow; deep, Master Shallow. [...]

Shallow: Peter Bullcalf o' the green!

Falstaff: Yea, marry, let's see Bullcalf.

Bullcalf: Here, sir.

Falstaff: 'Fore God, a likely fellow! Come, prick me Bullcalf till he roar again. (Shakespeare, n.d., 513) 